believe social organization to be synonymous with civilization, we may logically consider a native civilized who wears European clothes, rides a bicycle, sacrifices five shillings to the tote on Saturday and a penny to the collection on Sunday. But if we agree with Prof. McDougall that civilization is more and greater than social organization because it is the sum of the living moral and intellectual tradition of the people, our conception of native progress is widened and sobered. We feel our task in East Africa to be greater and more inspiring; more in need of scientific foresight and guidance than statesmanship is yet aware.

\title{
SOUTH-WESTERN DIVISION
}

The Autums Meeting of the Division was held by kind invitation of Dr. R. Eager, O.B.E., and the Committee of Visitors at Devon County Mental Hospital, Exminster, near Exeter, on Thursday, October 26, 1933.

The following members were present: Drs. R. A. G. Penny, C. F. Bainbridge, G. de M. Rudolf, E. Casson, P. W. Carruthers, A. H. Firth, B. M. Mules, A. S. Mules, A. Darlington, J. W. Fisher, B. J. Mullin, R. Craig, J. G. Smith, N. R. Phillips, E. Poynder, John Keay, W. R. Dawson, J. L. Jackson, R. Eager, Isabel G. H. Wilson, and S. Edgar Martin (Hon. Divisional Secretary).

The undermentioned attended as visitors: The Rev. J. Barney, Dr. L. A. Weatherly, Messrs. L. E. Claremont, W. H. Ross, E. W. Mayer, the Rev. Ian W. Elliot (Chaplain), Col. G. J. Ellicombe (Chairman of the Hospital Works Sub-committee), Mrs. D. E. Bainbridge and Dr. R. J. W. Minshull.

Dr. J. L. Jackson was in the chair.

Apologies for absence were received from the President (Dr. Turner), the Registrar (Dr. Rambaut), Dr. E. Barton White and others.

The minutes of the last meeting were read and confirmed.

On the proposition of Dr. C. F. Bainbridge, seconded by Dr. J. G. Smith, Dr. S. Edgar Martin was nominated as Hon. Divisional Secretary, and Dr. E. Barton White and Dr. J. L. Jackson as Representative Members of Council, the latter to be Chairman of the Division.

On the proposition of Dr. C. F. Bainbridge, seconded by Dr. N. R. Phill.ips, Dr. A. A. D. Townsend was nominated to serve on the Mental Nursing Advisory Committee to the General Nursing Council.

The following were elected as Ordinary Members :

John Langdon Favll, M.R.C.S., L.R.C.P., D.P.M., Assistant Medical Officer, Dorset County Mental Hospital, Herrison, Dorchester.

Proposed by Drs. J. J. B. Martin, G. W. T. H. Fleming and Stanley M. Coleman.

Michael John Wilmott Minshull, B.M., B.Ch.Oxon., Assistant Medical Officer, Devon Mental Hospital, Exminster, Devon.

Proposed by Drs. R. Eager, R. A. Greenwood Penny and S. Edgar Martin.

The place of the I934 Spring Meeting was left in the hands of the Hon. Divisional Secretary.

Dr. R. EAGER, O.B.E., then read a paper and opened a discussion on "Occupational: Therapy ",

The Rev. J. Barney, Drs. N. R. Phillips, E. Casson, G. de M. Rudolf and E. Poyider took part in the discussion, and Dr. EAGER replied to the points raised.

Dr. Eager had kindly prepared a printed route as a guide to enable inembers to make a tour of the hospital in order to view the various occupations which have been introduced since the beginning of the year, and this proved of great use. The members expressed their keen interest in everything they saw. The various occupations included, on the male side: Knitting of vests and pants; coir-mat making and upholstery; making of brown paper bags, netting, faceand dish-cloths, fire-lighters, etc.; brush and basket making, floor cloth weaving, rag-picking and cabinet making ; weaving (by automatic hand-looms) of blankets, serge, tweed and towelling ; making of rubber mats from disused motor tyres; printing and book-binding. On the female side: Tooth-brush, hair-brush and plaited straw basket making; envelope cutting; wool rug making and raffia work; book-binding and toy making, and other similar occupations to those seen on the male side.

A film was also shown of the various occupations carried on by the patients in the hospital.

An opportunity was also given to members of inspecting the new Nurses' Home.

Members were entertained to lunch and tea by the kind invitation of Dr. Eager and the Committee of Visitors, who were represented by Col. G. J. Ellicombe, Chairman of the Hospital Works Sub-committee, in the absence, through illness, of Major R. P. Kitson, Chairman of the Hospital Committee.

Col. Ellicombe gave a short history of the Devon County Mental Hospital, and mentioned 
that Sir John Bucknill and Sir James Crichton-Browne had been associated with the hospital in its early history.

Dr. J. L. JAckson proposed a hearty vote of thanks to Dr. R. Eager and the Committee of Visitors for their kind hospitality, and Dr. EAGER replied.

\section{NORTHERN AND MIDLAND DIVISION.}

The Autums Meeting of the Division was held, by the courtesy of Dr. E. L. Hopkins, at the County Mental Hospital, Mickleover, Derbv, on Fridav, October 27, 1933.

During the forenoon members visited the Reception Hospital and the Nurses' Home, both of modern construction and admirable design.

Members were kindly entertained to lunch, after which Dr. Shaw proposed and Dr. TuRner seconded a vote of thanks for hospitality. Mr. Alnerman Hawksley Edmunds, Chairman of the Visiting Committee, responded.

Dr. Shaw took the chair at 2 p.m.

The minutes of the previous meeting, having been published and circulated, were confirmed and signed.

The following thirty-three members were present : Drs. Alexander, Archdale, Baine, Bruce, Brunton, Drury, East, Eaves, Fitzgerald, Forrester, Fox, Henderson, Hopkins, Horton, Macarthy, D. Macmillan, D. M. Macmillan, Mackenzie, Malloy, Menzies, O’Reilly, Pearce, Panton, Parfitt,

Potts, Reid, Russell, Shaw, Shilvock, Scott, Freize Stephens, Taylor and Turner.

Four visitors also attended.

Apologies for absence from forty members were communicated.

The following candidate, after ballot, was duly elected an Ordinary Member of the Association :

Hugh Thomson Kirkland, M.A., M.B., Ch.B., D.P.M., Medical Officer, Erdington House ; "Northolme", 192, Reservoir Road, Erdington, Birmingham.

Proposed by Drs. J. J. O'Reilly, C. W. Forsyth and A. M. McCutcheon.

The following letter from the General Secretary was received: "Bye-law 26. Your application on behalf of the Northern and Midland Division for the Council's authority to elect the Divisional Secretary and Representative Members of Council by show of hands instead of by ballot was placed before the Council to-day, and received their sanction."

The following communication from the Council was received : ". . . that in order to save time at the General Quarterly and Annual Meetings, candidates should, whenever possible, be elected at Divisional Meetings."

The Reports of the Divisional Committee and Representative Members of Council were received.

Drs. Edgerlev, Dove Cormac and Archdale were elected to serve on the Divisional Committee of Management.

An invitation to hold the Spring Meeting, 1934, at Prestwich Mental Hospital was received from Dr. Blair, and accepted.

Dr. HUGH BARBER delivered an interesting lecture on “The Life-History of the Renal Dwarf". Many cases were illustrated by photographs reflected on the screen by means of an epidiascope, and one of Dr. Barber's patients attended the meeting.

Dr. E. J. Fitzgerald read a paper entitled "Syphilis and the Mental Treatment

Act ".

The meeting closed at 4.30 p.m.

Members were afterwards entertained to tea.

\section{SCOTTISH DIVISION.}

The Autums Meering of the Scottish Division was held at Riccartsbar Mental Hospital, Paisley, on Friday, December I, 1933.

The following were present: Prof. D. K. Henderson, Drs. R. B. Campbell, Douglas McRae, Donald Ross, W. Ford Robertson, R. D. Hotchkis, Neil T. Kerr, J. H. Macdonald, C. A. Crichlow, Ronald Stewart, W. D. Chambers, W. McAlister, Alex. Dick, D. C. Dewar, T. Ferguson Rodger, William Telfer, William Blyth, D. R. MacCalman, L. M. D. Mill, George M. Bell, Kate Fraser, Sheila Macpherson, C. J. Shaw, W. Boyd, A. D. I. Bruce and Angus MacNiven.

Dr. J. H. MACDonald presided at the outset of the meeting. He made sympathetic reference to the illness of Dr. W. M. Buchanan, the Divisional Secretary, and moved that the 